\title{
Study on Self-learning of Business English Students by Network
}

\author{
Sun $\operatorname{Lu}^{1, a^{*}}$ \\ ${ }^{1}$ Harbin University of Commerce, Harbin, China, 150028 \\ aSUN_LU1980@163.com
}

Keywords: Business English; Network; Self-learning; China; Learning Environment

\begin{abstract}
Traditional Business English teaching and learning takes place only in the classroom setting with textbooks. It provides students with zero business English environments. Consequently, students are confronted with "environmental shock" at their work place after graduation. With amazingly rich resources, network-based Business English teaching broadens student's horizon and facilitates student's autonomic learning. It's a promising way for Business English teaching in China.
\end{abstract}

\section{Introduction}

According to the new curriculum requirements released by the Ministry of Education, this paper puts forward a new model of college English teaching reform, namely, the institutions of higher learning should make full use of multimedia and network technology, and priority is given to improving the new teaching model with the teacher adopting a single classroom teaching mode. New teaching model should take modern information technology, especially network technology as the support, and it should not be restricted by time and place, in order to make English teaching go toward the personalized learning and autonomous learning direction [1]. This means that the function of network teaching in English teaching with the leap-forward development has gradually transited from the auxiliary role to the teaching of the front desk, plays a dominant position. It has been proved that web-based foreign language teaching is not only the result of the progress of science and technology in the information age, but also the combination of cognitive psychology and sociolinguistics.

According to the China international trade association international business English research council statistics in 2014, business English courses offered in our country had reached more than 400 colleges and universities, and there were tens of thousands of international business English graduates. With the rapid development of international business and continuously expanding enrollment of colleges and universities, due to the current situation of many learners and the shortage of business English teachers, the importance of business English autonomous learning is especially striking. As is known to all, effective English learning is situational, being taken place in a specific environment. The so-called environment is in addition to the physical meaning of existence and the existence of psychological meaning, namely the mind[2]. The implementation of effective language acquisition depends on teachers' attention to two types of environment: Learning business English particular situation. Business work process is essentially a kind of communication and a state of mind in the business environment and business workers. Business English, business English syllabus stresses, the teaching goal is to develop in the international business environment's ability to communicate in English. It cultivates the practical ability, and helps students get familiar with the different business environment and in a variety of business environment for effective communication in English.

\section{The English Self-Learning}

During the past 20 years, self-learning has attracted wide attention of English teaching. HenriHolec as early as the concept of "autonomy" (autonomy) is introduced into English teaching. Holec, schools should set up two 
teaching goals: one is to help students acquire language and communication skills; the second is to help students obtain the independent learning ability.

China English is becoming more and more aware of learner autonomy, which is the ultimate goal of English education, especially in the 1990s under the influence of constructivism theory. Constructivism emphasizes that human knowledge is not pure objective; construction is not to teach others but the learner himself; it is not a independent form but a process of interaction with the external environment; teaching should take students as the center, and give the students to control and manage their rights and opportunities; Teaching is the main task of the designer design the student's learning environment, create favorable conditions of learning for students[3].

\section{Traditional business English teaching environment}

Traditional business English learning environment is the basic setup in the classroom and paper textbooks, providing students with zero business environment, the real business environment, don't ask, don't see don't want to cause students after graduation to work environment shock, do not knowledge. In addition, the teacher is the main body of teaching, and the student is seen as a passive receiving object of knowledge. Teaching means consist of monotonous textbooks and chalk + blackboard and tape recorder. This kind of traditional business and language education only imparting knowledge, training application ability and autonomous learning ability, is essentially treats people like animal behaviorist thought, ignore the person's subjective initiative, suppresses the students inner needs, limits the students' development, lack of energy, make teaching result in talent cultivation model simplification[4].

\section{The business English teaching based on network environment}

Based on the network of business English teaching is to build suitable for each student's learning environment, from unification to spread out, to give priority to with the student individuality learning, and to provide a large number of real business and English environment and knowledge input, let the student have immersive feeling, rich material to expand the horizons of students. It has the following features:

Provide abundant learning resources of students' autonomous learning environment. Autonomous learning is based on the biggest characteristic of foreign language learning and advantages of the network. In this teaching environment, the students use multimedia courseware and network abundant learning resources on their own learning, not limited by time and place of (something, any time, anywhere) [5]. Teaching software will all content displayed in the form of the menu, students to learn knowledge of chapters or by simply click on the website, such as economy, trade, finance and so on, to get into the specific content, regulate their own learning progress, democracy, exploration of the learning process, to obtain abundant learning resources, on the basis of constantly constructed on the basis of the original experience in itself on the understanding of new knowledge and develop their cognitive structure. In addition to a lot of business knowledge, the network to the students with a large number of real English language materials, ensure the English pronunciation, so that the students can not blindly rely on teachers and teaching materials. Translation skills in reading, writing, listening and speaking training can closely arranged at the same time, both excellent pictures and texts, images move feeling, easy to leave deep impression to the student, learning content to remember unforgettable, not easy to produce the feeling of boring. There are a variety of media resources and services designed specifically for business English teaching website provide rich resources, extensive reading, let the student to carry on the original movies, learn to sing English songs, listen to VOA, CNN and BBC radio news. Computer network is set up for students and teachers, classmates and the outside world (e.g., English speakers) Bridges, and create real English environment and opportunities for learners [6]. 
Provide a large number of real business English materials. Real material comes from the real business world, fills the limited and blank knowledge in the textbook, and stimulates students' learning interest and enthusiasm. The combination of computer and network and business English teaching shows the business activities to the students all aspects of the real scene, such as receiving, phone calls, meetings, business negotiation, inquiry, offer, counter-offer, shipment, insurance, and payments, etc., in order to help the students master elegant business etiquette. It also provides a variety of real business writing style, such as product introduction, charts, contract, application forms, meeting minutes, memos, business correspondence, reports, advertising, specifications, and let the students practice in business genres of reading and writing. The real charm lies in its material information accurate, fresh, high credibility, and plays a role of bridge, the students of business theory knowledge and the realbusiness world. A lot of input to let the students no longer a stranger to the real business activities, and can be appropriately and effectively in cross-cultural business communication.

For effective cultural import. Cultural import is an important content of English teaching. Computer and network teaching to help students learn business knowledge and the knowledge of English at the same time, understand the culture of the English-speaking countries, made up for the inadequacy of Chinese environment to learn English. Intuitive learning make students see and hear more vividly in English-speaking countries people real language and body language in business situations, deeply understand English national culture[7].

\section{The construction of autonomous learning environment strategy}

Adjust the teacher's role. Teachers had the fundamental change and adjustment, the role of teacher identity by the original knowledge and instill a single transition to the diversity and pluralism of multilayered generalists. (1) The learners and researchers. Network teaching requires teachers to have familiar with modern computer network technology, the use of operating skills, and the ability to self-developed multimedia courseware[8]. The teacher must have a lot of business knowledge and English, and constantly improve their knowledge structure, become and students study together learned yue people, on the network platform and students to achieve good interaction, online dialogue, and online discussions, communicate with each other. (2) The designers. Teacher is the designer of the learning resources and process by applying the theory of teaching systematic design model and according to the specific situation of the students, curriculum design, teaching content and teaching outline, design learning tasks and courseware, teaching information, guarantee the smooth implementation of the teaching plan. (3) Help scholars and guide. Teachers from the knowledge disseminator and authority as a help scholars and guide, is autonomous learning facilitator and guide students to use resources. (4) Monitoring. Teacher to student's learning process monitoring, found that students learning obstacles in time, ensure the smooth progress of learning activities. (5) Evaluation. Teachers of students learning task completion, strategies, grasp the situation, the study effect evaluation, and promote the internalization of evaluation.

Establish the subject status of the students. Taking the teaching of students how to learn, students learning situation, the characteristic as the teaching guide and road signs, according to their learning to identify the type of individual differences, play their role in design and control of the process of learning, cultivate their ability of autonomous learning.

Pay attention to students' emotion. In a sense, learning a foreign language is on one's own character and emotion, attack. Has a lot of input environment is not the same as students can learn a foreign language, language input must through the affective filter is likely to become a language. The emotional state of students is an important factor that affect the learning success or failure of the teacher must be good at guiding students to regulate their emotions, maintain a strong learning motivation[9].

Perfect the software and hardware environment. Computers and networks in foreign language teaching environment requires the corresponding hardware and software, otherwise it is an armchair strategist, 
hardware construction needs multimedia broadcast equipment, high-performance computer, digital camera, digital camera, scanner, and easy to carry the large capacity of data storage devices (such as notebook computers, mobile hard disk, CD burners, etc.). Pay attention to the construction of teaching courseware, under the guidance of scientific thought in linguistics design high quality courseware, fight potboiler[10].

\section{Conclusions}

Traditional business English learning environment is basically set in the classroom and paper textbooks, providing students with zero business English environment and causing students to the work environment of shock. This kind of traditional business and language education only imparting knowledge, training application ability and autonomous learning ability, substitute teacher, a professor of the students' learning and experience, ignore students' subjective initiative, suppresses the students inner needs, limits the students' development. And network teaching, with its abundant learning resources is to broaden the student's field of vision, and promote students' autonomous learning, is the direction of business English teaching development in the future.

\section{Acknowledgements}

This paper is supported by Philosophy and Social Scientific Research Project Foundation of Heilongiiang Province (No.14D008) and ((No.14C009). At the same time this paper is supported by the Higher Education Reform Project (No.JG2014010815) of Heilongjiang Province.

\section{References}

[1]Avery.G. C, Leadership for Sustainable Futures Achieving Success in a Competitive World, first ed., Edward Elgar, 2010.

[2]Bacon.C. S, Enhancing Critical Thinking Skills through Conversation in the Classroom,J.Sci.Commun.11 (2011) 178-179.

[3]Cottrell. S, Critical Thinking Skills: Developing Effective Analysis and Argument, first ed., American Irwin, 2011.

[4]Cowen.T, Creative Destruction: How Globalization is changing the World's Cultures, first ed., Princeton University Press, 2012.

[5]Elsa Dent, The Leadership Pocketbook, first ed., Management Pocketbooks, 2003.

[6]Michalak.S. J, Liberal Education, J.Sci.Commun.156 (2011) 78.

[7]Quilliam. S, Positive Thinking, third ed., United States: DK Publishing, New York, 2008.

[8]Stamm. B. V, Managing, Innovation, Design, and Creativity, third ed., John Wiley \& Sons Ltd, Washington, 2003.

[9]Taylor. W. M, Informal Logic, J.Sci.Commun. 10 (2012) 19-22.

[10]Thompson. J. N, On Being a Successful Graduate Student, first ed., University of California, 2005. 